\title{
The "Americanization" of Critical Theory: A Legacy of Paul Piccone and Telos
}

\author{
Timothy W. Luke
}

\section{Introduction}

Much of the "critical theory" being written in Western Marxist, Frankfurt School or new populist registers all across North America today must be tied back in some fashion to the lifework of Paul Piccone and the journal Telos. Since Telos has continued developing and diversifying its discourses of critique after Piccone's death in 2004, whatever multiple identities these new schools of critical theory have acquired since the end of the Cold War during 1991, and the advent of the War on Terror in 2001, also cannot be easily untied from ongoing developments with this unusual publication. Along with its multiple networks of radical writers and global audiences of loyal readers, Telos today still pushes hard to be ahead of the curve in critical theory, while staying attentive to its own eclectic philosophical craft.

Quite unlike many other self-acclaimed radical publications, which spin thick webs of rhetoric about their engaged political resistance, but then never open their pages to an ongoing expression of truly concrete critical differences, Telos has spent over 40 years of publishing many of the most electrifying, diverse, and controversial figures that one could read in one place. From many varied nationalities, classes, theoretical movements, religions, ideological schools, cultures, and political perspectives, a wide array of people have worked with Telos at pivotal points in their intellectual lives (Luke 2005b). From these engagements, the nature of critical theory in the U.S.A. has been continuously transformed for over four decades. In this respect alone, and even though many might have disagreed with him and the journal's writings, Paul Piccone and Telos have had left a discernible influence on North American cultural, political, and social critical theory that will not soon be forgotten (Luke 2005a).

Because it was the core of Paul Piccone's scholarly life, as well as the development of an American critical theory, one should assess the impact and importance of Telos since 1968. In keeping with the ferment of that moment, the journal continuously has touted its origins as an experiment "launched on May 1,1968" in Buffalo, New York. From within labyrinths of Buffalo's branch of the State University of New York system, this tiny publication was first published under the editorial guidance exerted by a small group of graduate students mostly in the discipline of philosophy. Whether it was its out-of-the-way site of origin or its founders' peculiar personalities, Telos successfully has maintained the essence of its founders' original aspirations, namely, to publish works "committed to philosophical synthesis. ... We are concerned to offer alternatives to the many forces operating to further the existing fragmentation of knowledge and human existence. It must be emphasized that 'philosophical synthesis' is not intended to exclude any philosophical school; it directed against only those philosophical efforts which are sorely technical, and thereby isolated, achievements" (Telos 1968: cover).

For all the twists and turns taken since publishing its first issue, which featured brief articles on Franz Brentano, Wesley Salmon's reading of Karl Popper, a comparison of Goethe and Hegel, an analysis of Averroism with modern science, and a socio-historical interpretation of the scientific revolution (written by Paul Piccone), Telos continues to espouse the merits of this foundational intellectual design today. It remains wide-open to a range of unconventional thinkers seeking a philosophical synthesis, while fostering deep and systematic doubts about everything that has 
come to be associated in the popular imagination with the interactions of New Left 1960s' radicals, the modern liberal democratic state, research universities, the perversities of world markets, post-1945 global geopolitics, and contemporary mass culture.

\section{The Initial Telos Project}

During its first decade of publication, Telos brought into wider discussion most of the Western Marxist tradition that had been ignored, forgotten or suppressed in most of the anti-Soviet Western capitalist countries for decades. Ranging from debates within the Second or Third Internationals, more radical resistances against the pre-1914 Social Democratic parties or post-1918 Marxist-Leninist communist parties, criticisms of the new Bolshevik regime in the 1920s or the Stalinist purges of the 1930s, Telos revisited many ignored, if not forgotten, cultural, intellectual, and political battles within all of these organizations and institutions. At the same time, it also initiated translations of rare unobtainable Frankfurt School authors as well as explorations of works by Gramsci, Lukács, Pannekoek and Korsch as these figures faced repression from fascist, liberal democratic or communist authorities. With these reconsiderations of the failings of "actually existing socialism" everywhere in the world, Telos proved invaluable as forum for debate as well as source for texts unavailable anywhere else in English.

Telos authors during these early years recognized that Marxism prior to 1914 had slipped-along with the social democratic parties of Europe since the late 1880s - into the dyspeptic affectations of being "revolutionary" while no longer being "revolution making." This Bernsteinian embrace of an evolutionary socialism made most of Second International Marxism into a relatively conformist credo. Lenin's return to Russia with the assistance of the German High Command in April 1917 soon tumbled over the already tottering February Revolution with the expanding forces of that unorthodox soviet voluntarism celebrated in his State and Revolution. Riding that spirit into the October revolution, Marxism as "a philosophy of praxis" got another chance. Without this extraordinary intervention of revolutionary will by the Bolsheviks, as Piccone (1994:176) notes, "Marxism would have gone the way of other 19th century philosophies of progress, like those of Comte, Spencer, and various Social Darwinists." The U.S.S.R.'s growing deformation, however, by bureaucratic collectivism, industrialization from above, and Stalinist militarism after 1928 all sparked, in turn, the rediscovery of the Hegelianized reading of Marxism from the 1920s through 1960s in the West that Telos widely popularized after 1968.

The engagement of the journal with Western Marxism during the 1960s and 1970s was quite significant, because it took an abidingly serious interest in these largely forgotten, ignored or suppressed traditions of Marxian critique that had been frozen over by the Cold War. Still, Telos also meant to come to terms with the activities and programs of "actually existing socialism," which clearly stumbled from atrocity to atrocity after 1928. Once it began this investigation, however, many Telos authors' critiques quickly returned to the atrocious qualities of the Reds going back to 1918, while growing also more suspicious of the U.S.S.R. in the present as those authoritarian patterns continued in Czechoslovakia, Angola, Nicaragua, Afghanistan, Ethiopia, and Poland. The larger New Left movements during the 1960s also tried to seize a hold on this ambivalent and amorphous critical discourse, which was about "as sophisticated as any available in Europe at the time" in order gain "a political vision and a better selfunderstanding" of itself in a world so far beyond the origins of classical Marxism (Piccone 1977:180).

For some, it soon was apparent that Marxism's ideological resume really could never serve as the basis for the New Left "in itself" to become a truly transformative force with any then existing class formations. Hence, the first and second decades of Telos were preoccupied with reassessing Western Marxism, Soviet Marxism, and the original Frankfurt School as "part of that long series of failed efforts in the 20th century to relegitimate socialism and mass democracy as radical emancipatory alternatives to capitalism and liberalism, well after the Bernstein debate had indicated the extent to which the former could easily degenerate into a mere extension of the latter" (Piccone 1994:197). Looking back over this period, Piccone and others argued that the historical function of Telos in the ferment of 1968 "has been primarily to provide Marxism with a decent burial” (Piccone 1977:181).

These contradictions also plotted coordinates for Piccone, and other authors in Telos, to see the New Left in the West, and entrenched Communist regimes everywhere they were in power, in a far more critical light. Launched during 1968 with its "the Prague Spring" and "the events of May" in Paris, 1968, Telos proved to be relentlessly critical of political maneuvers and ideological contortions made in the West to defend "actually existing socialism" after 1968. It was neither willing to apologize for the August 1968 invasion of Czechoslovakia by the Warsaw Treaty 
Organization under Moscow's leadership, nor the complete failure of the New Left student movements to realize any real political change through the end of the Vietnam War in 1975. Hence, Telos caused chagrin in many ideological camps. It was against the Vietnam War; but, it did not, at the same time, celebrate anticolonial revolutionaries in either North or South Vietnam. Similarly, it never patted Moscow or Beijing on the back for boosting other anti-Western, but allegedly revolutionary, forces in the Middle East, Asia, Latin America, or Africa. All along, it also expressed deep doubts over celebrating Nixon's and Ford's "strategic withdrawal" from Cambodia and Vietnam, and it never ignored the tragic aftermath of the Khmer Rouge's and Vietnamese Communist Party's full accession to power there.

By the 1980s, then, Telos was carving out its own unique theoretical spaces, which proved suitable for articulating far more maverick modes of materialist criticism, as its editorial offices also moved to New York from St. Louis. Along with Marcuse and Habermas, newer unusual figures (like Jean Baudrillard, Murray Bookchin, Michel Foucault, Cornelius Castoriadis, Agnes Heller, Christopher Lasch or Antonio Negri) as well as more dissident voices from Eastern Europe (ranging from Polish labor radicals, Charter 77 figures, Budapest School thinkers, East German dissidents, Praxis 48 writers, or new Soviet émigrés) peppered the ebb-and-flow of Telos debates. Not surprisingly, the gradual crumbling of the U.S.S.R. and the rise of neoliberal regimes in London and Washington started to preoccupy both Paul Piccone and many other Telos authors during these years. The uncritical celebration of "civil society" in Eastern Europe as well as the "open market" in the West ignited many disputes among the Telos networks, and Piccone's unorthodox approach to both of these dismal discourses lead to splits_-both personal and philosophical_-among its editors, authors, and readers.

In this sense, as Piccone (1988:25) observed, it was increasingly true by the late 1980s and early 1990s that "analyses of specifically American themes from perspectives rooted neither in the old Critical Theory nor in the Theory of Communicative Action nor, for that matter, in standard objectivistic social science are increasingly finding their way in the pages of Telos." As its traditionalism, or eclecticism, or even conservatism, seemed to be rising, Telos was indeed opening its pages in the Reagan years and after to a quite variegated collection of critics who were all concentrating their attention on the rising tides of neoliberal transformation at work all around the world.

\section{| The Critique of Global Neoliberalism}

The prevailing political order still in force during the formative years of Telos was one, as Harvey (2005:11) identifies it, of an "embedded liberalism" organized to ensure that "market processes and entrepreneurial and corporate activities were surrounded by a web of social and political constraints." Whether it was the United States, Japan or Western Europe, and despite various ideological agendas, a very strong institutional apparatus underpinned and enforced a clearly evolving collective social contract. That is, there was a general consensus (Harvey 2005:10-11),

that the state should focus on full employment, economic growth, and the welfare of its citizens, and that state power should be freely deployed, alongside of or, if necessary intervening in or substituting for market processes to achieve these ends. Fiscal and monetary policies usually dubbed "Keynesian" were widely deployed to dampen business cycles and to ensure reasonably full employment. A 'class compromise' between capital and labor was generally advocated as the key guarantor of domestic peace and tranquility. States actively intervened in industrial policy and moved to set standards for the social wage by constructing a variety of welfare systems (health care, education, and the like).

These policies delivered fairly predictable high rates of economic growth into the early 1970s, especially since the U.S. was willing to rack up major trade imbalances with the rest of the world as it imported their industrial and agricultural products within transnational grids for intra-corporate exchange from all across its protected zones of liberal democratic capitalism. However, after 1979, a new agenda formed around making aggressive alterations to this social contract. And, it was clear that this "neoliberal project is to disembed capital from these constraints" (Harvey 2005: 11).

When pushed, many Telos authors also took the "embedded liberalism" of the postwar era to task for not going far enough and fast enough to fulfill its own collective promise. Tripped up by new class bureaucrats' insufficient ability to use state power in realizing greater social democracy, and an excessive regulatory will pushed beyond the point of diminishing return, liberal democratic capitalism proved to be less democratic, light on liberalism, and loose with capitalism. This increasing incompetent approach to managing Keynesian social welfare practices, in turn, led quickly down a revisionist road to neoliberal structural adjustments. 
Again, Harvey's view of neoliberalism is succinct, and it captures many of the shifts in the larger economy and society that Telos began addressing more closely during the last thirty years. Along with the degradation of embedded liberalism, neoliberal practices are a complex system which, in the final analysis,

\begin{abstract}
"values market exchange as 'an ethic in itself, capable of acting as a guide to all human action, and substituting for all previously held ethical beliefs', it emphasizes the significance of contractual relations in the marketplace. It holds that the social good will be maximized by maximizing the reach and frequency of market transactions, and it seeks to bring all human action into the domain of the market. This requires technologies of information creation and capacities to accumulate, store, transfer, analyze, and use massive databases to guide decisions in the global marketplace. Hence neoliberalism's intense interest in and pursuit of information technologies (leading some to proclaim the emergence of a new kind of 'information society'). These technologies have compressed the rising density of market transactions in both space and time (Harvey 2005:3-4).
\end{abstract}

As the neoliberal project unfolded in Europe, China, and the United States during the 1980s and 1990s, Telos willingly sought out both alternative contemporary and unusual past sources of unorthodox resistance to challenge these relentless institutional and ideological developments. Unlike Harvey, however, Piccone and Telos pushed past Marx, Habermas, and even Gramsci. As Piccone suggested in 2001, “forget about Marxism; it’s all over" (2004:157).

Consequently, from Carl Schmitt's critique of the aimless drift of fully commercialized market societies, or Christopher Lasch's criticism of professional-mechanical elites intent upon building rootless empires of global corporate capital on the backs of embattled local communities to Paul Gottfried's doubts about the conservative agendas of Reagan, Bush (41), and Bush (43) or Alain de Benoist's questioning of the European Union's bureaucratic confederalism as inimical to Europe's ordinary people, Telos stepped away from the ineffectual, and increasingly irrelevant, criticism made by the contemporary Frankfurt School. These critical failures, as personified by Habermas and his followers in "the communicative turn," or other avowedly liberal thinkers, who were struggling to maintain the illusion that the embedded liberalism of 1933 to 1973 might somehow survive in new "third way" politics, have proven very costly since the 1980 s.

In the American context, then, Telos increasingly contested the discourses and policies of both neoliberalism and professional-technical classes working on its behalf. As Bourdieu and Wacquant (2008:364) argue, these practices and people appear as agents of modernization who ironically "are seeking to remake the world by making a clean slate of the social struggle, depicted today as so many archaisms and obstacles to the nascent new order, but also by cultural producers (scholars, writers, artists) and even political figures of the left, the majority of whom still see themselves as progressive." It is precisely these contradictory cultural practices and often regressive policies that Telos special issues have targeted as conflicts defining the emergent post-Cold War era since the late 1980s.

At best, the Blair government and Clinton administration sanded off the roughest edges of Thatcher's, Reagan's, Deng's, Pinochet's, Salinas' or Putin's aggressive neoliberal globalism coupled, when needed and/or expedient, occasional coats of conservative nationalism and flat-out consumerism. The nearly complete failure of neoliberal governments to either anticipate or eradicate radical Islamicists' assault on the West after 1983 is not shocking, because of its relentless commercial colonization of traditional local societies in the Middle East, Africa and Asia as well. As they fall-back in panic to police state legislation at home and half-hearted interventions abroad after 2001, the neo-liberals also have come under withering attacks from many critical theorists writing in Telos.

During 1988-1989, the impeding collapse of Gorbachev's campaigns for perestroika across the U.S.S.R. along with the Soviet Union's stalemate in Afghanistan clearly fascinated Telos writers; but, during the swirling celebrations of allegedly more liberating moves toward civil society institutions in the East and market-based solutions in the West after 1989, Telos stood back, choosing to explore the theories and practices of more contrarian left and right thinkers and movements for different insights. Studies tied to the works of Carl Schmitt, Karl Polanyi, Max Weber, Murray Bookchin, Paul Gottfried, Norberto Bobbio, Christopher Lasch, and Zygmunt Bauman carried Telos through the "end of history" years of 1989-1991. Meanwhile, the journal increasingly scrutinized the savage outcomes of neoliberal triumphalism all around the world as it developed special issues and symposia on the crisis of education, federalism, tradition, populism, racism, postmodernism, multiculturalism, fascism, globalization, religion or terrorism. Other special issues on the postsocialist transition in Eastern Europe, crises in Canada, the European Union, and the Northern League in Italy, also were, in part, worried ruminations about the brazen moves and hidden agendas of the neoliberal era.

Hyperreality on a global scale is just one moment of materiality into which the practices of rampant neoliberalism have morphed. The simulation of society, acceleration of economy, and reduction of government since 1980 
express the neoliberal fetishization of markets, deregulation, individuals, and globalization around "the generation by models of a real without origin or a reality: a hyperreal. . it is the map that engenders the territory" (Baudrillard 1983:2). Neoliberalism with its aggressive globalizing networks, worn-down domestic governments, and overtaxed local communities exalts "the individual" interacting with millions of others in "the market." Neoliberalism's most bitter truth, as its own continuous commercial chaos and periodic power outages illustrate, "no longer has to be rational, since it is no longer measured against some ideal or negative instance. It is nothing more than operational" (Baudrillard 1983:3).

Indeed, neoliberalism's engines of engagement rapidly link everything to the corporate world's alleged "best practices." Of course actually existing capitalism varies from place to place, but its fixations on the negative liberties of individuals, firms, and goods "to be free" often solidifies into a strange symbolic imperialism tied into a system of signs as well as a power grid for practices. The rollbacks of Keynesian welfare state protections and benefits begins "a liquidation of all referentials," or, even worse, via the magic of microeconomic models, "their artificial resurrection in systems of signs, a more ductile material than meaning in that it lends itself to all systems of equivalence, all binary oppositions, and all combinatory algebra" (Baudrillard 1983:4).

In hedge funds, commodity futures, credit histories, margin accounts, debt obligations, or payment patterns, the ordinary individual and the national market get flipped around as hyperreal (con)fusions. With the advent of mass-mediated hyperrealities, the map does engender territory and territorially-instantiated map simultaneously do initialize and finalize the neoliberal project: "substituting signs of the real for the real itself, that is, an operation to deter every real process by its operational double, a metastable, programmatic, perfect descriptive machine which provides all the signs of the real and short-circuits all its vicissitudes" (Baudrillard 1983: 4).

Regardless of their roots in purportedly left-wing movements or allegedly right-wing groups, Telos authors have engaged many of neoliberal developments-from multiculturalism to globalization to post modernism to informationalization - as political confusions, economic diversions or social immobilizations. Many of these policies are, in turn, grounded upon "symbolic violence supported by a relationship of constrained communication depicted to enforce submission, and whose particular feature consists in this case in its universalization of certain particulisms bound up within a singular historical experience, misconstruing them for what they are, and interpreting them as universal" (Bourdieu and Wacquant 2008: 364). All too often, gleaming hyperrealities have proven to be gritty realities hyped up to disserve the many to reward the few. Telos has called out these empty universalizing trends for being what they are, namely, schemes for enforcing more elite control and endorsing less democratic involvement. And, the journal makes these strong interventions against such trends no matter what their proponents' varying center, left or right political agendas prove to be.

\section{Telos Today}

The practices and policies of the liberal welfare state began to crack, and then finally just crumble in years spanning the U.S.A.'s expanded involvement in Vietnam after the Gulf of Tonkin incident and its diplomatic humiliation in Iran during the Islamic revolutionaries' hostage-taking at the U.S. Embassy. And, as it has been suggested here, Telos came into its own and a unique outlet for a new North American current of critical theory. Being equally suspicious of the egalitarian designs of Great Society bureaucrats in the U.S.A. and the empty promises of "actually existing socialism” in the U.S.S.R., the thinkers working with Paul Piccone and Telos kept up the Frankfurt School's critique of overbearing and overreaching state power, while anticipating the quickening spin of the neoliberal turn all around the world. Although Telos did not always contest neoliberalism programmatically, Piccone and others increasingly took neocommunitarian, anticorporatist or populist stands against neoliberal practices as Thatcher and Reagan followed from the economic, political and social crises of the 1970s.

On the other hand, Telos ironically seconded some of the criticisms made by libertarian economists, like Friedman, von Hayek or von Mises, against corporate statism, because, in part, they paralleled comparable critiques frequently made by Western Marxists, traditional anarchists, ordinary workers or disserved citizens. Believing in the importance of individual life and collective liberty enjoyed with the happiness implied by economic opportunity, cultural personal integrity, and individual freedom, Piccone respected the possibilities implied by trusting in individuals, markets, and less interventionistic governments.

Yet, the Telos approach to neoliberalism deeply distrusted it as the solution to all the crises caused by the 
crumbling Keynesian welfare state. Piccone and many Telos contributors saw the state failing, but they did not simply conclude along with the neoliberals that the market would succeed. Good government would not automatically arise from cooperating uncritically with big business, emulating the culture of corporate capitalism or accepting managerialist best practices to a new normalizing regime. Rather, Telos argued over how the same excessively rationalized, arrogantly overweening, and uncritically propounded logics of command-and-control that crippled liberal welfare states also profoundly plagued transnational neoliberal markets.

Therefore, the lines of flight taken in Telos crisscrossed the many processes, practices, and projects of the neoliberal turn with an eclectic mix of resistances that took comfort neither from the orthodoxies of the New Left nor with the conformities of the New Right. These tendencies in Telos were evolving as Thatcher and Reagan came to power, and as the U.S.S.R. began to topple with its ill-considered adventures in Afghanistan. Telos writers saw how Keynesian welfare policies, Great Society corporatism, and Fordist social practices were unraveling, but they also foresaw how these failing projects were being captured, co-opted or crushed by the neoliberal experiments of more collaborative governance, public/private partnerships, and laissez-faire social policies.

From another perspective, Bourdieu regarded this turn toward neoliberalism as the project of resisting "the liberal counter-revolution" arriving in the values and practices of the United States "refashioning the world in its own image: the mental colonization" generated by willing submission to free markets, globalist de/re-industrialization programs, and the moralism of individual materialism that climaxes in "a kind of generalized and even spontaneous "Washington consensus" (Bourdieu and Wacquant 2008:367). In their critique of the new class, Telos authors trod down the same path as Bourdieu in his equally dogged critique of the cynical producers of neoliberal reason, namely, "the expert" and "the communications advisor."

As this "actually existing neoliberalism" (Brenner and Theodore 2002:349-379) took hold, Telos let go most of their last ties to orthodox liberal-progressive alliances. And, in doing so, Piccone and Telos began answering the growing neoliberal hegemony from 1985 onward with even more unorthodox inspirations taken from nonconformist sources of critique, ranging from Christopher Lasch to Alain de Benoist, radical orthodoxy in theology to 19th century populism in politics, Carl Schmitt to Murray Bookchin, the Northern League in Italy to municipal communitarianism in the U.S.A. When viewed apart and alone, these inspirations could appear to be backward-looking, right wing or narrowly parochial. Still, as they unfolded, and when taken together, these twists-and-turns through outlaw territories with maverick allies are, in fact, a credible and consistent critical response to the corrupting sweep of neoliberalism. By 2000, the neoliberal consensus heading into the twenty-first century essentially was touting the hegemonic need to believe in TINA — or "there is no alternative" to the pervasive normalizing forces of itself (Marcuse and van Kempen 2000). Nonetheless, Telos continued to dedicate itself to pushing back hard with every alternative to neoliberal practices that conventional thinking could, would, or had dismissed.

In this respect, Telos still is, as Gross (2004:45) observed, following in Piccone's footsteps "searching for ways to create critical, autonomous personalities who would then forge healthy political institutions," and it is pursuing this goal in the same manner than Piccone spent the latter years of his life. Even though Gross disputes the success of their engagement with this task, Piccone and those working with him remain devoted to "the development of a contrarian spirit through the recollection of traditional forms of thought or ways of being that have been defeated or declared out-of-state" (Gross 2004:45). These modes of thinking and acting are essential for mobilizing the political consciousness and moral conscience needed to find the "concrete horizons" promising something better beyond, beneath or beside neoliberalism (Piccone 1996:163).

\section{Conclusions}

After four decades, and despite the premature lament about their demise made by Russell Jacoby (one of Telos' earliest and long-lasting critical voices), many of the journal's writers-by seeking the committed philosophical synthesis and critique that North America needs in its intellectual life-have popped up in the mainstream of global cultural and political discourses as "public intellectuals." Of course, Telos first translated and granted greater public currency to many radical intellectuals more read and recognized in Europe, Japan or Australasia, like Gramsci, Husserl, Lukacs, Marcuse, Sartre, Horkheimer, Adorno and Habermas. However, as the years went by, Russell Jacoby, Cornelius Castoriadis, Paul Feyerabend, Christopher Lasch, Andre Gorz, Joel Kovel, Alvin Gouldner, John Zerzan, Thomas Fleming, Murray Bookchin, Jean Bethke Elsthain, Paul Gottfried, and Jerry Brown also were given voice 
in Telos. Even though the journal was rarely in the spotlight, it always has been at the forefront of every major development in critically-driven social and political theory in North America.

Since 2004, Telos has continued to dissect the even more excessive neoliberal permutations of today's transnational cultural, economic and political networks under Russell Berman's editorship. As a set of practical protocols or the raw rules of a ragged regime for global power, these networks are dangerous. Indeed, their selfseeking corporate capitalist elites, entrenched neoliberal policies, and purposeful ecological degradation do not add up to the essential characteristics of an allegedly new and refined "cosmopolitan age." They are instead the outlines for the increasingly lean and mean matrix of mystification deployed to deny opportunities to the many for the greater social production and individual consumption of that good life to be enjoyed by only a few.

Where other liberal theorists believe increasing democratization, mounting rationalization, and deepening commercialization enhance life, Piccone and Telos saw something much different. From out of the strange neoliberal economy and civil society developing during the post-;Cold War era, the Telos analysis robustly articulates the Americanization of critical theory. In sharp contrast to many others, its authors, much more commonly and far more accurately, see a decreasing deliberative potential, an emptier democratic life, a worsening illiteracy, an irrational order, and a pernicious culture infiltrating the first spaces and last recesses of everyday life. The journal's suspicions about, and tough criticisms of, radical Islamist movements and their authoritarian politics is another part of this continuing intellectual critique. As Berman 2008:5) notes in Telos' 40th anniversary issue, the journal still seeks to explore the post-1968 world "in terms of aspirations and failure: the search for the good life in the polis side by side with the redemptive aspiration to overcome a degraded world through the pursuit of new/post-material values."

From 1968 to 2003, Piccone was a vital force in the articulation of a uniquely North American approach to critical theory, albeit one counterintuitively more poised at reacting quite frequently to historic developments abroad. Over time, a North American ground for this new critical theory was found in the Telos' critique of the research university, multiculturalism, mass culture, fascism, leftist movements, environmentalism or radical Islam. And, these thirty-five years spanned the days from May 1, 1968 and past September 11, 2001. During this time, Telos also fostered an elaborate analysis of many thinkers, movements, ideologies, countries, practices, and institutions that Piccone helped build. So this larger critique continues to build in Telos after his untimely passing in 2004, and the journal increasingly has evolved as its current subtitle suggests, namely, it is "A Quarterly Journal of Politics, Philosophy, Critical Theory, Culture, and the Arts."

The nature of intellectual discourse, the conduct of scholarly communication, the significance of public debate, and the circulation of critical thought, at the same time, have changed as much as the world over the past four decades (Luke 2005a). Remarkably, Telos is still thriving and continues to be regarded as essential reading for those writers hoping to think outside the box, and then maybe act inside the sweep of their readers' greatest hopes. The cataclysmic confusion of the Bush (43) years will rock the American republic on its foundation for years, and the instability created by neoliberalism is coming under increasing criticism and growing doubt as the deeper challenges of radical Islam, global climate change, economic inequality, authoritarian state capitalism, and cultural emptiness go largely unanswered in the U.S.A. and elsewhere. Despite their detractors, and building upon their prescient anticipation of all these failings in neoliberalism, the new critical theorists associated with Telos are still among the best sources to consult first for the answers needed for knowing, and then doing, what is right.

Telos authors generally admire Adorno's worries about the immediate effectiveness of any critique, but they do not stand with him in complete solidarity on the inability of thought to grasp the totality of all that must be thought critically about, and resisted without reservation. Similarly, they always have refused the postmodern reluctance to not come forth as active engaged subjects. The critique of science, technology, and work also runs through Telos, although not as strong as it could be, but clearly it is vital enough to sustain the struggle.

Gauging the impact of Telos on the intellectual life of the English-speaking countries, not to mention Englishreading populations in non-English-speaking countries is a formidable task. The mere survival and continued success of a publication like Telos after four decades in many ways is an awesome testimonial in itself. To have thrived from the age of "LBJ" and the nightmarish wars in southeast Asia in 1968 to the era of "W" and his misbegotten wars in Southwest Asia in 2008, Piccone achieved a great deal. Today Telos remains an on-going success in whose pages one can document the times of Nixon and Brezhnev, the Iranian Revolution, Thatcher and Reagan, revolts in Eastern Europe, Gorbachev and Yeltsin, the collapse of the USSR, Clinton and Gore, the European Union, market Leninism and China's commercialization, environmental crises, Deng Xiaoping and Vladimir Putin, and the new war of terrorism. It is an achievement matched by few other publications in the world. That figures as diverse as 
Herbert Marcuse and Juergen Habermas, Vaclav Havel and Jerry Brown, Michel Foucault and Christopher Lasch, or Axel Honneth and Paul Gottfried, Carl Schmitt and Seyla Ben-Habib came together in its pages all suggest that this journal's intellectual impact in the world by Americanizing critical theory is another remarkable attainment. Yet, even more significant here is how consistently unorthodox, aggravating, and exceptional much of the Telos project has been from any political perspective, while these many pathbreaking intellectual achievements were being attained.

\section{References}

Baudrillard, Jean. 1983. Simulations. New York: Semiotext.

Berman, Russell A. 2008. "Introduction." Telos 143 (Summer): 3-6.

Bourdieu, Pierre and Loïc Wacquant. 2008. "The New Planetary Vulgate." Pierre Bourdieu Political Interventions: Social Science and Political Action, selected and introduced by Franck Poupeau and Thierry Discepolo. London: Verso.

Brenner, Neil and Nick Theodore. 2002. "Cities and the Geographies of 'Actually Existing Neoliberalism.' Antipode 34:349-379.

Gross, David. 2004. “Combating Modernity: Piccone and the Role of Tradition in the Present Age." Telos 131 (Summer):33-45.

Harvey, David. 2005. A Brief History of Neoliberalism. Oxford: Oxford University Press.

Luke, Timothy W. 2005a. "From Pedagogy to Performativity. The Crisis of Research Universities, Intellectuals, and Scholarly Communication." Telos 131 (Summer): 13-32.

---.2005b. "The Trek with Telos: A Remembrance of Paul Piccone (January 19, 1940-July 12, 2004).” Fast Capitalism 1.2 (http:// www.fastcapitalism.com).
Marcuse, Peter and Ronald van Kempen. 2000. "Conclusion: A Changed Spatial Order." Globalizing Cities: A New Spatial Order, edited by Peter Marcuse and Ronald van Kempen. Oxford: Blackwell.

Piccone, Paul. 2008. Confronting the Crisis: Writings of Paul Piccone, edited by Gary Ulmen. New York: Telos Press Publishing.

----.2004. “Telos in Canada: Interview with Paul Piccone.” Telos 131 (Summer):152-166.

---.1996. "The Tribulations of Left Criticism: A Reply to Palti." Telos 107 (Spring):155-169.

---.1994. "From the New Left to the New Populism." Telos 101 (Fall):173-208.

---.1988. "20 Years of Telos." Telos 75 (Spring):3-25.

----.1977. “Internal Polemics." Telos 31 (Spring):211-219.

---.1976. "From Tragedy to Farce: The Return of Critical Theory." New German Critique 7 (Winter):36-46.

---..1971. "Phenomenological Marxism.” Telos 9 (Fall):3-31. 